Article

\title{
Promising Cr-Doped ZnO Nanorods for Photocatalytic Degradation Facing Pollution
}

\author{
Fatemah. H. Alkallas ${ }^{1}$, Amira Ben Gouider Trabelsi ${ }^{1, *}$, Ramzi Nasser ${ }^{2}$, Susana Fernandez ${ }^{3} \mathbb{D}$, Ji-Ming Song ${ }^{2} \mathbb{D}$ \\ and Habib Elhouichet 4,5 \\ 1 Department of Physics, College of Science, Princess Nourah Bint Abdulrahman University, P.O. Box 84428, \\ Riyadh 11671, Saudi Arabia \\ 2 Anhui Province Key Laboratory of Chemistry for Inorganic/Organic Hybrid Functionalized Materials, \\ School of Chemistry \& Chemical Engineering, Anhui University, Hefei 230601, China \\ 3 Renewable Energy Unit, Energy Department, CIEMAT, Avda. Complutense 40, 28040 Madrid, Spain \\ 4 Physics Department, College of Sciences, University of Bisha, P.O. Box 551, Bisha 61922, Saudi Arabia \\ 5 Laboratory of Characterizations, Applications and Modelisation of Materials LR18ES08, \\ Sciences Faculty of Tunis, University of Tunis El Manar, Tunis P.O. Box 2092, Tunisia \\ * Correspondence: aatrabelsi@pnu.edu.sa; Tel.: +966-557-570-310
}

check for updates

Citation: H. Alkallas, F.; Ben Gouider Trabelsi, A.; Nasser, R.; Fernandez, S.; Song, J.-M.; Elhouichet, H. Promising Cr-Doped ZnO Nanorods for Photocatalytic Degradation Facing Pollution. Appl. Sci. 2022, 12, 34. https://doi.org/10.3390/app12010034

Academic Editor: Fernandez

Velasco Leticia

Received: 20 November 2021

Accepted: 16 December 2021

Published: 21 December 2021

Publisher's Note: MDPI stays neutral with regard to jurisdictional claims in published maps and institutional affiliations.

Copyright: (c) 2021 by the authors Licensee MDPI, Basel, Switzerland. This article is an open access article distributed under the terms and conditions of the Creative Commons Attribution (CC BY) license (https:// creativecommons.org/licenses/by/ $4.0 /)$.

\begin{abstract}
Chromium ( $\mathrm{Cr}$ )-doped zinc oxide $(\mathrm{ZnO})$ nanorods with wurtzite hexagonal structure were prepared through a thermal decomposition technique. The concentration effect of the Cr doping on the structural, morphological, and optical properties of the $\mathrm{ZnO}$ nanorods was established by correlating various measurements: transmission electron microscopy (TEM), photoluminescence (PL), X-ray diffraction (XRD), X-ray photoelectron spectroscopy (XPS) and several UV-visible studies. The obtained nanorods were investigated as photocatalysts for the photodegradation process of methyl orange (MO), under UV-vis light illumination. Different weights and time intervals were studied. A $99.8 \%$ photodegradation of $\mathrm{MO}$ was obtained after $100 \mathrm{~min}$ in the presence of $1 \mathrm{wt} . \%$

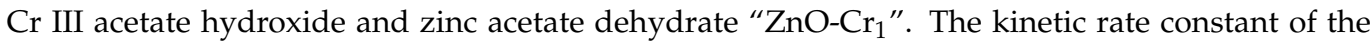
reaction was found to be equal to $4.451 \times 10^{-2} \mathrm{~min}^{-1}$ via a pseudo-first order rate model. Scavenger radicals demonstrated the domination of $\mathrm{OH}^{\bullet}$ radicals by those of $\mathrm{O}_{2}^{\bullet-}$ superoxide species during the photodegradation. The interstitial oxygen site $\mathrm{O}_{\mathrm{i}}$ is proposed to play a key role in the generation of holes in the valence band under visible irradiation. The $\mathrm{ZnO}-\mathrm{Cr}_{1}$ photocatalyst displayed good cycling stability and reusability.
\end{abstract}

Keywords: ZnO nanorods; Cr-doping; oxygen vacancies; charge separation; photocatalysis

\section{Introduction}

Application of organic pollutants like dye molecules, cadmium (Cd), and chromium $(\mathrm{Cr})$ is common in industry [1-10]. Their effluent contains various colored combinations that are difficult to manage [11]. This greatly impacts the natural water surface and causes several side effects for living creatures [10]. Therefore, organic pollutants require appropriate treatment before being discharged into the water [12].

Different studies have been performed to obtain clean and cost-effective methods of solving dye wastewater problems. Earlier techniques addressing this problem succeeded in realizing a partial degradation of water pollutants [13]. This limitation has been resolved through a new technique, i.e., the photolytic method, that guarantees effective degradation of dye molecules [14]. The photolytic process refers to the rapidity of the photoreaction in the presence of semiconductors as catalysts [15]. This technique is low-cost, non-toxic, and safe environmentally, which makes it promising for the dyes industry [10]. Indeed, photocatalytic degradation ensures a significant decolorization of dye wastewater. These unique properties of the photocatalytic method have attracted a lot of interest where the desire for a better environment exists. 
The innovative physical properties associated with $\mathrm{ZnO}$ nanostructures have attracted a lot of interest due to their good performances in various applications. The size and shape of $\mathrm{ZnO}$ nanostructures play a major role in generating new application domains [16]. This greatly affects the physical properties like photoluminescence, transmittance and conductance as well as the photocatalytic activity and potential window measurements. Indeed, zinc oxide $(\mathrm{ZnO})$ displays distinctive characteristics such as: large band gap, elevated chemical stability, facile synthesis, high excitonic energy, good surface reactivity, photosensitivity and non-hazardous nature $[11,16,17]$. This expands its use as a photocatalyst in the photodegradation process of pollutants. Nevertheless, there are some limitations to its application as a photocatalyst, such as the high probability of the recombination process between photoinduced electrons and holes [17]. Previous studies have aimed to ameliorate the separation rate of the photo-induced charge carriers via changing the electronic properties of $\mathrm{ZnO}$, i.e., the band structure. This was achieved through metallic ion doping [17-19]. A slight doping using metallic ions enables energy traps formation through reserving the host phase-structure and the original vital properties of the photocatalysts. The increase in the trap centers and the transfer of photoinduced charge carries of the pollutant will accelerate the photodegradation process [20]. Such morphological and structural changes greatly affect its properties, leading to new electrochemical applications.

Metal ion doping remains one of the major factors affecting the photocatalytic response of $\mathrm{ZnO}$. Further factors have a significant impact on the photocatalytic response of $\mathrm{ZnO}$ such as the morphology control of the photocatalyst. The proper determination of the adequate size and shape of photocatalysts is essential, to optimize their properties and give better results. This requires a non-toxic, low cost, high yield synthesis technique of photocatalyst semiconductor materials. The thermal decomposition method using zinc acetate dihydrate is one of these promising techniques. It is a reasonable, facile, cost effective, highly yielding and rapid method for pure $\mathrm{ZnO}$ nanocrystals production [21,22]. This technique has demonstrated its efficiency in earlier studies [23-25]. Indeed, nickel-doped $\mathrm{ZnO}$ nanorods have been successfully synthesized by thermal decomposition technique and introduced into a spintronics application [26]. Recently, a new thermal decomposition synthesis technique has been developed to obtain chromium $(\mathrm{Cr})$-doped $\mathrm{ZnO}$ nanorods as cool nano-pigments, which was shown to have good efficiency and properties [27].

Furthermore, dye molecules are one of the most hazardous and polluting waste materials today. Their high stability in normal environmental conditions is the major reason for this. In particular, wastewater effluent that is rich in these molecules remains a challenge facing natural water sources and our ecosystem. The application of these molecules extends to cover various domains, particularly, the optoelectronic domain. This is related to their promising optical response in the visible domain. Such molecules belong essentially to the AZO group of molecules, i.e., components formed by the " $\mathrm{R}-\mathrm{N}=\mathrm{N}-\mathrm{R}^{\prime \prime}$ " function, such as congo red (CR) and methyl orange (MO). Several studies have addressed the physical and chemical methods of dye molecule hindrance [28]. Nevertheless, these methods remain unable to stop dye contamination of the environment and stop their transformation into adsorbents. One of the promising paths to achieve a complete degradation of these dye molecules is photocatalysis. This latest technique ensures complete destruction of the pollutants by turning them into mineral organic dyes such as $\mathrm{H}_{2} \mathrm{O}$ and mineral acids.

A wide range of photocatalysts descend from various semiconductors like $\mathrm{TiO}_{2}$ [29], $\mathrm{SnO}_{2}$ [30], $\mathrm{Zn}_{2} \mathrm{SnO}_{4}$ [31], $\mathrm{CdS}$ [32], and $\mathrm{ZnS}$ [33]. Such photocalyst-based materials are costefficient and eco-friendly. Zinc oxide $(\mathrm{ZnO})$ exhibits high efficiency in the photocatalytic degradation of some organic dyes compared to other material [34-36]. ZnO dye molecules are promising materials for reducing environmental contamination.

In this paper, we will consider the performances of $\mathrm{Cr}$-doped $\mathrm{ZnO}$ nanorods on photodegradation. We studied the weight ratios of different $\mathrm{Zn}$ and $\mathrm{Cr}$ precursor salts. These were used as photocatalysts in the UV-photodegradation of methyl orange (MO), as an example of an organic dye pollutant. Different UV-vis studies were developed. 
This study opens the door to $(\mathrm{Cr})$-doped $\mathrm{ZnO}$ nanorod functionalization for a future optoelectronic application.

\section{Materials and Methods}

\subsection{Synthesis Route of Cr-Doped $\mathrm{ZnO}$ Nanorods}

Pure and $\mathrm{Cr}$-doped $\mathrm{ZnO}$ nanorod samples were synthesized using the thermal decomposition technique. The typical synthesis route of $\mathrm{Cr}$-doped $\mathrm{ZnO}$ followed the procedure given in our previous work [11]. Zinc acetate dihydrate " $\mathrm{Zn}\left(\mathrm{CH}_{3} \mathrm{COO}\right)_{2} \cdot 2 \mathrm{H}_{2} \mathrm{O}$ " (Winlab, purity: 99.999\%) and chromium (III) acetate hydroxide " $\left(\mathrm{CH}_{3} \mathrm{CO}_{2}\right)_{7} \mathrm{Cr}_{3}(\mathrm{OH})_{2}$ " (SigmaAldrich, St. Louis, MO, USA) were used as precursors for synthetization of $\mathrm{Cr}$-doped $\mathrm{ZnO}$ nanorods. The thermal decomposition route process can be summarized as follow. Prior to adding chromium (III) acetate hydroxide " $\mathrm{Cr}$ III OAc hydroxide, $(\mathrm{CH} 3 \mathrm{CO} 2)_{7} \mathrm{Cr}_{3}(\mathrm{OH})_{2}$ ", zinc acetate dihydrate " $\mathrm{Zn}$ OAc dehydrate, $\mathrm{Zn}(\mathrm{CH} 3 \mathrm{COO})_{2} 2 \mathrm{H}_{2} \mathrm{O}$ " was grinded for $2 \mathrm{~h}$ via a single vibrating mill machine with agate mortar and a milling ball ( $3 \mathrm{~cm}$ in diameter). Then, the milled powder was subjected to another $2 \mathrm{~h}$ of grinding after adding the desired amount for each sample from chromium (III) acetate hydroxide. The obtained fine powder was introduced into a covered $50 \mathrm{~mL}$ alumina crucible and placed in an oven for $4 \mathrm{~h}$ at $350{ }^{\circ} \mathrm{C}$ for the decomposition process. The weight ratio of $\left(\mathrm{CH}_{3} \mathrm{CO}_{2}\right)_{7} \mathrm{Cr}_{3}(\mathrm{OH})_{2}: \mathrm{Zn}\left(\mathrm{CH}_{3} \mathrm{COO}\right)_{2} 2 \mathrm{H}_{2} \mathrm{O}$ varied from 0 to $5 \mathrm{wt} . \%$. A summary of the prepared samples is given in Table 1.

Table 1. Cr-doped $\mathrm{ZnO}$ nanorod description: weight concentration of $\mathrm{Cr}$ III OAc hydroxide and zinc acetate dihydrate changes in percentage of the investigated sample $\mathrm{ZnO}-\mathrm{Cr}_{0}, \mathrm{ZnO}-\mathrm{Cr}_{1}, \mathrm{ZnO}-\mathrm{Cr}_{3}$ and $\mathrm{ZnO}-\mathrm{Cr}_{5}$ photocatalytic reaction sample treatment.

\begin{tabular}{|c|c|c|}
\hline Sample & $\begin{array}{c}\text { Weight Concentration of Cr III OAc } \\
\text { Hydroxide and Zinc Acetate Dihydrate in } \\
\text { Percentage (\%) }\end{array}$ & $\begin{array}{l}\text { Photocatalytic Reaction: } \\
\text { Methyl Orange (MO) }\end{array}$ \\
\hline $\mathrm{ZnO}-\mathrm{Cr}_{0}$ & 0 & $\begin{array}{c}165 \mathrm{~mL} \text { from } 10 \text { ppm aqueous of methyl orange } \\
+ \\
3.3 \mathrm{mg} \text { from each sample }\end{array}$ \\
\hline $\mathrm{ZnO}-\mathrm{Cr}_{1}$ & 1 & Then stirred for $10 \mathrm{~min}$ followed by $5 \mathrm{~min}$ \\
\hline $\mathrm{ZnO}-\mathrm{Cr}_{3}$ & 3 & equilibrium. \\
\hline $\mathrm{ZnO}-\mathrm{Cr}_{5}$ & 5 & $\begin{array}{l}\text { A } 3 \mathrm{~mL} \text { of each solution was filtered than } \\
\text { examined each } 10 \mathrm{~min}\end{array}$ \\
\hline
\end{tabular}

The characterization of the final powder confirmed the formation of wurtzite hexagonal phase without other $\mathrm{ZnO}$ phases, or any phases based on chromium as discussed elsewhere [11]. This refers to the stability of the host structure of $\mathrm{ZnO}$ crystal, although with the addition of $\mathrm{Cr}$ atoms due to substituting the $\mathrm{Zn}$ sites in the lattices by $\mathrm{Cr}$, which is usually suggested for a low concentration of $\mathrm{Cr}$ [11]. The morphological and structural properties of the synthetized $\mathrm{Cr}$-doped $\mathrm{ZnO}$ nanorod were shown via transmission electron microscopy "TEM" (type JEOL-JEM-1230). PL measurements were obtained through an He-Cd laser of $325 \mathrm{~nm}$ excitation wavelength. XRD was performed using monochromatized $\mathrm{CuK} \alpha$ radiation $(\lambda=1.5418 \AA)$. $X$-ray photoelectron spectroscopy (XPS) measurements were analyzed via ESCALSB 250 electron spectrometer under ultra-high vacuum $\left(p<10^{-9} \mathrm{mbar}\right)$ The data were collected at normal incidence, i.e., the sample surface was vertical to the emission angle. A mono-chromatic AlK $\alpha$ source $(1486.6 \mathrm{eV})$ functions using a power of $420 \mathrm{~W}$ $(30 \mathrm{~mA}$ and $14 \mathrm{kV})$, where the $\mathrm{C} 1 \mathrm{~s}$ core $(284.6 \mathrm{eV})$ was used as reference to calibrate the peak positions of other elements. The photocatalytic activity (PAC) of the synthesized Cr-doped $\mathrm{ZnO}$ nanorods was inspected under UV-vis irradiation via a UV-vis spectrophotometer (Unico UV-2100, Waltham, MA, USA). 


\subsection{Photocatalytic Reaction during the Photodegradation Process of the Methyl Orange}

In order to perform the photocatalytic reaction, $165 \mathrm{~mL}$ from $10 \mathrm{ppm}$ aqueous dye molecule methyl orange (MO, Fluka Analytical) was mixed with $3.3 \mathrm{mg}$ from each sample of the synthesized $\mathrm{Cr}$-doped $\mathrm{ZnO}$ nanorods. To ensure the fine dispersion of catalysis (Cr-doped $\mathrm{ZnO}$ nanorod powder), the mixed solution was stirred for $10 \mathrm{~min}$ followed by $5 \mathrm{~min}$ sonication to reach adsorption-desorption equilibrium (see Table 1). Then, a 12 (UV-Vis) lamp (253.7 nm wavelength) enclosed in silica tube was immersed in the solution of the photocatalytic reaction. We isolated the photocatalytic reaction unit using a suitable cover to avoid all hazardous UV radiation. The mixed solutions were continuously agitated during the UV-illumination. About $3 \mathrm{~mL}$ from the solution was extracted each $10 \mathrm{~min}$ and then filtered with a $0.2 \mu \mathrm{m}$ pore size of PTFE-membrane syringe filter to remove the freed catalyst powder. The absorption of the filtered solutions was examined, as per our previous work [11], via a UV-vis spectrophotometer at the maximum characteristic peak of $\mathrm{MO}(\approx 464 \mathrm{~nm}$ wavelength). Figure 1 represents a schematic graph of the photocatalytic experiment.

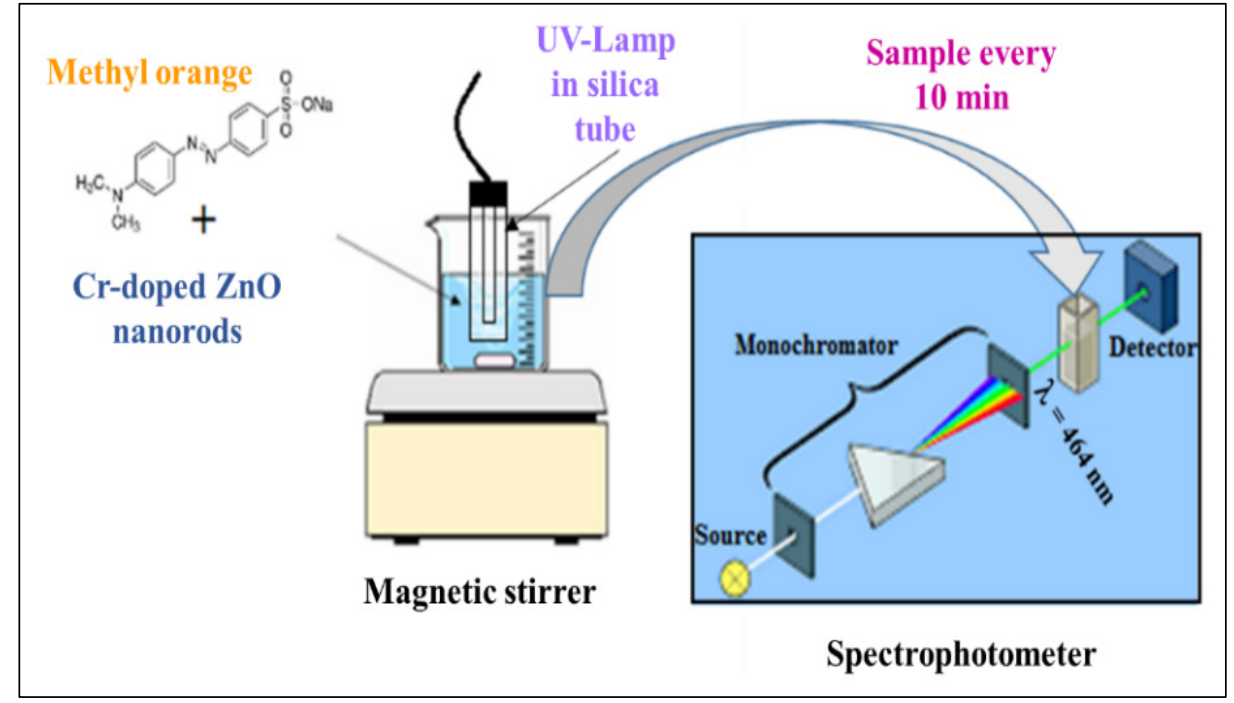

Figure 1. Schematic representation of the photocatalysis process every $10 \mathrm{~min}$.

\section{Results}

\subsection{XRD Measurements}

XRD measurements of the synthesized $\mathrm{ZnO}-\mathrm{Cr}$ samples are represented in Figure 2. The $\mathrm{ZnO}$ diffractograms confirmed the hexagonal phase crystallinity of the entire samples [37]. No changes in the structure phase were noticed after adding $\mathrm{Cr}$ ions. The absence of impurity phases shows the proper localization of the $\mathrm{Cr}$ ions on the sites within the $\mathrm{ZnO}$ lattice. However, the minor shift position changes of the diffraction peaks to a lower angle by $\mathrm{Cr}$ doping reflects the substitution of $\mathrm{Zn}$ ions with those of Cr. Nevertheless, the full width at half-maximum "FWHM" of the main diffraction peaks also increases by increasing Cr doping, highlighting their good incorporation. This demonstrates the effective doping process given here. Thus, the XRD measurements demonstrated the high crystallinity of the various studied samples. 


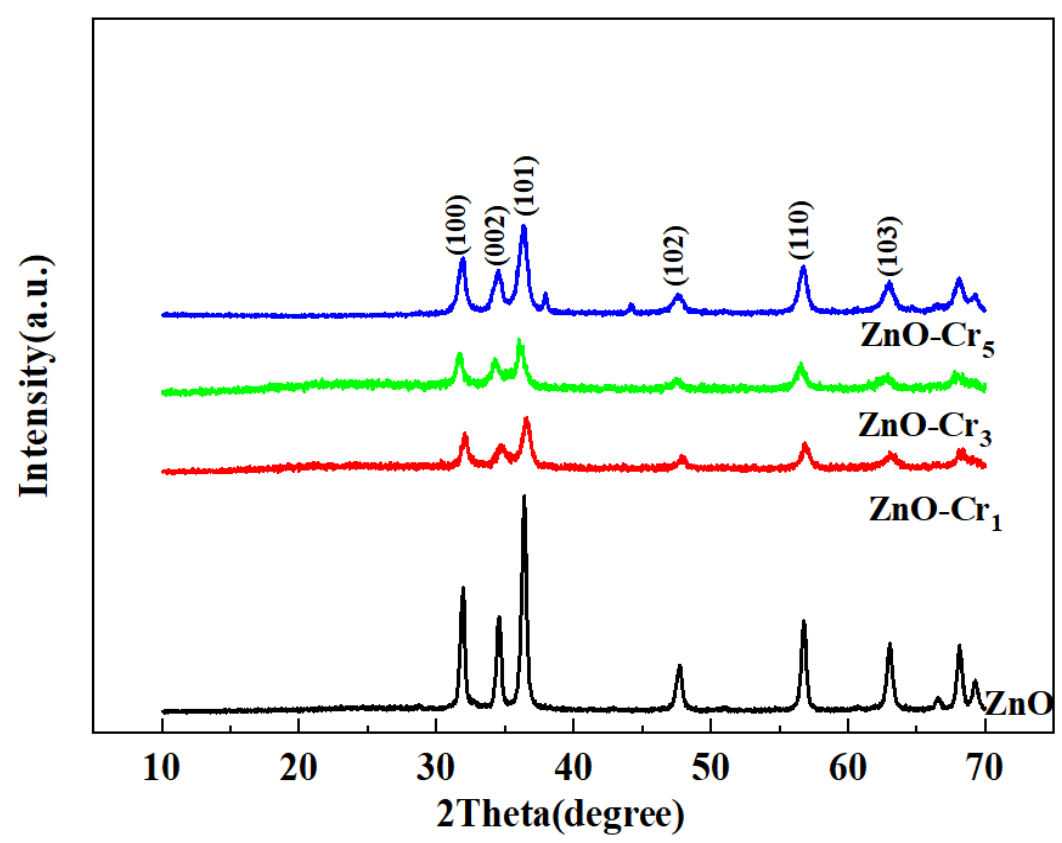

Figure 2. XRD diffractograms of undoped and $\mathrm{Cr}$-doped $\mathrm{ZnO}$ nanorods.

\subsection{TEM Characterization of $\mathrm{Cr}$-Doped $\mathrm{ZnO}$ Nanorods}

The morphological characteristics of the $\mathrm{Cr}$-doped $\mathrm{ZnO}$ were investigated byTEM. Figure 3 shows an image obtained for the $\mathrm{ZnO}^{-\mathrm{Cr}_{1}}$ sample as an example of the grown nanorods. It displays homogenous nanorod structures, where cylindrical forms ending with a spherical termination were observed. Here, the growth temperature plays the major role in the nanorod growth. The elevated temperature used during the growth process (of about $\mathrm{T} \approx 350^{\circ} \mathrm{C}$ ) facilitates the nanorods' crystal growth through the $\mathrm{c}$ axis. This confirms earlier studies where 1D nanostructure shapes, i.e., nanorods, were obtained through thermal decomposition $[11,37]$.

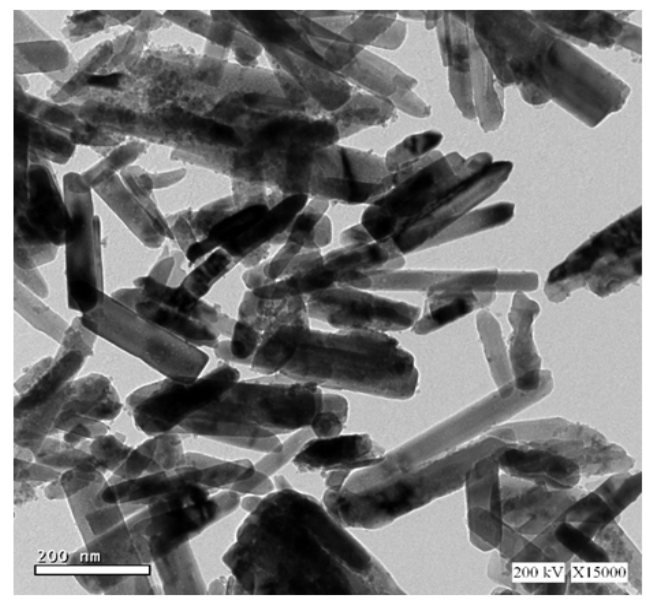

Figure 3. TEM micrograph of the $\mathrm{ZnO}-\mathrm{Cr}_{1}$ sample with different magnifications using $\times 200 \mathrm{~nm}$ magnification.

\subsection{XPS Analysis}

The surface composition and chemical states were analyzed via XPS for the $\mathrm{ZnO}-\mathrm{Cr}_{1}$. Here, binding energies of the various elements present in the $\mathrm{Cr}$-doped $\mathrm{ZnO}$ nanorods are given. The obtained survey shows the signature of $\mathrm{Zn}, \mathrm{O}$ and $\mathrm{Cr}$ elements only in the synthetized nanorods (Figure 4a). High-resolution imaging of the $\mathrm{Zn}_{2 \mathrm{p}}, \mathrm{O}_{1 \mathrm{~s}}$ and $\mathrm{Cr}_{2 p}$ peaks was performed. Figure $4 \mathrm{~b}$ exhibits two highly symmetric peaks located at 
$1021.70 \mathrm{eV}$ and $1044.8 \mathrm{eV}$, assigned respectively to the $\mathrm{Zn} 2 \mathrm{p}_{3 / 2}$ and $\mathrm{Zn} 2 \mathrm{p}_{1 / 2}$ states. These peaks are commonly identified in $\mathrm{ZnO}$ nanomaterials [37,38]. Indeed, the narrow $\mathrm{Zn}$ $2 p_{3 / 2}$ band originates from the $\mathrm{Zn}^{2+}$ ions in an oxygen-deficient $\mathrm{ZnO}$ lattice [39,40]. This also demonstrates the dominance of the $\mathrm{Zn}^{2+}$ state for the $\mathrm{Zn}$ ions present on the surface. Figure $4 \mathrm{c}$ shows a peak positioned at $530.7 \mathrm{eV}$ ascribed to the $\mathrm{O} 1 \mathrm{~s}$. The broadening of this peak reflects the increase of oxygen defects or chemisorbed groups $(\mathrm{OH})$ in oxygen ions usually bonded to $\mathrm{Zn}$ ions forming the nanorods [39,40]. The $\mathrm{Cr}$ doping here is established by the location of the two symmetrical peaks at $576 \mathrm{eV}$ and $586 \mathrm{eV}$, assigned to $\mathrm{Cr} 2 \mathrm{p}_{3 / 2}$ and $\mathrm{Cr} 2 \mathrm{p}_{1 / 2}$, respectively (Figure $4 \mathrm{~d}$ ). The separation energy between these two peaks is about $10 \mathrm{eV}$, which is related to $\mathrm{Cr}$ dopants integrated into the $\mathrm{ZnO}$ lattice, i.e., on $\mathrm{Zn}$ sites, as $\mathrm{Cr}^{3+}$ ions instead of $\mathrm{Cr}^{2+}$ ions [41,42].
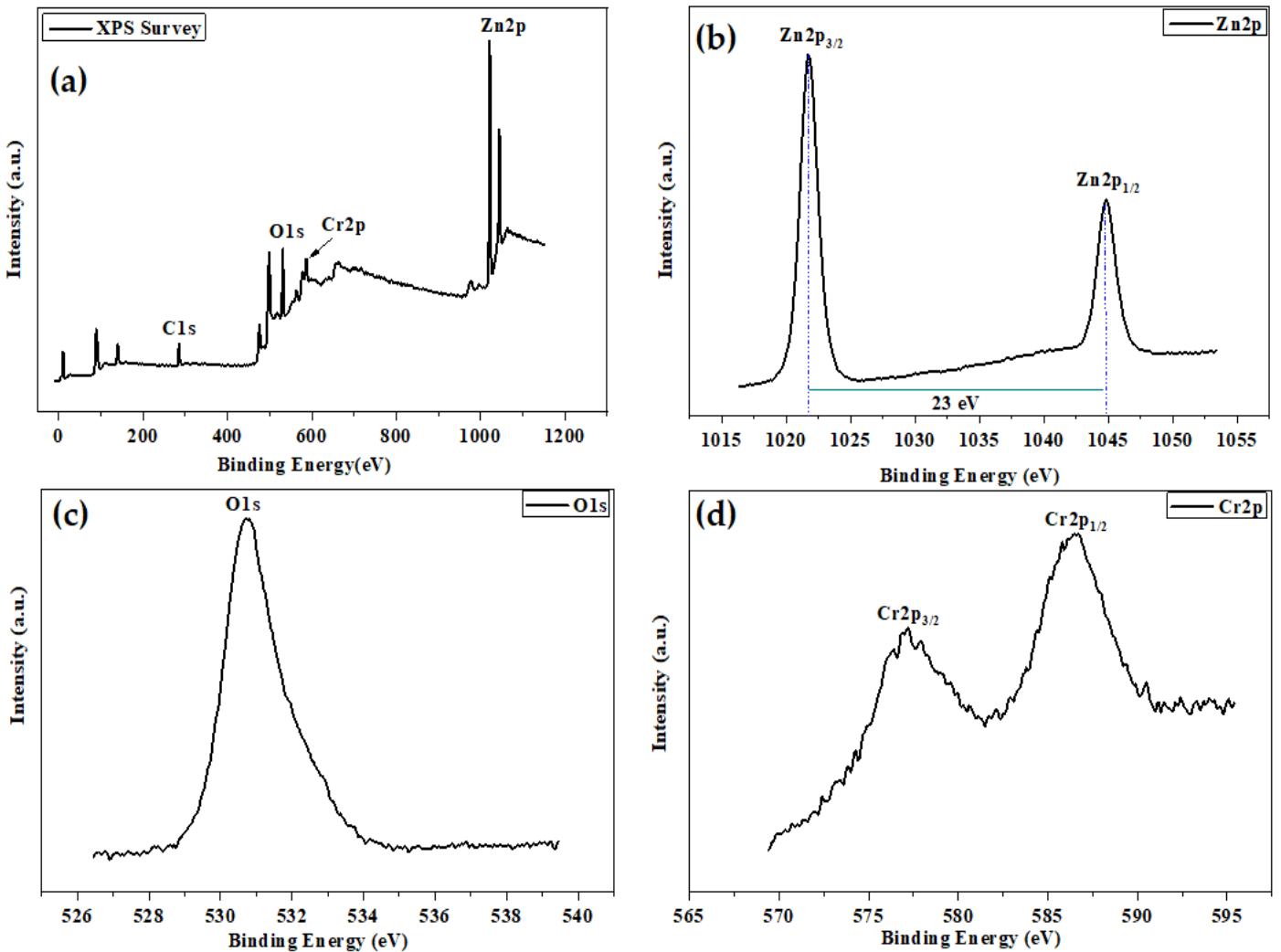

Figure 4. (a) XPS survey of Cr-doped ZnO nanorods. The XPS spectra of the: (b) Zn-2p, (c) $\mathrm{O}_{1 \mathrm{~s}}$; (d) $\mathrm{Cr}-2 \mathrm{p}_{3 / 2}$ and $\mathrm{Cr}-2 \mathrm{p}_{1 / 2}$ core level regions.

\subsection{Photoluminescence Analysis}

Photoluminescence (PL) analysis illustrated the electronic structure of the undoped and $\mathrm{Cr}$-doped $\mathrm{ZnO}$ samples, further to the energy states of the impurities and defects. PL measurements were obtained using an He-Cd laser at $325 \mathrm{~nm}$ excitation wavelength. A sharp PL spectrum was located at the limited domain of UV, which covered the entire visible range for the different investigated samples, i.e., undoped and $\mathrm{Cr}$-doped $\mathrm{ZnO}$ samples (Figure 5). The PL band located in the UV-domain could be attributed to both the free exciton recombination affecting the near band emission [43] and the donor-acceptor transition [14,44-47]. Such a band is kept at the same energy position, which is in good agreement with the weak change of the band gap energy Eg with $\mathrm{Cr}$ doping as was reported in our previous work [11]. Eg was found to be equal to 3.238, 3.221, 3.206 and $3.202(\mathrm{eV})$

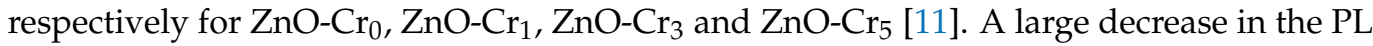
band intensity was observed by enhancing $\mathrm{Cr}$ doping, which is related to the degradation of the crystalline quality as revealed by XRD analysis. Various sharp peaks were also found in each spectrum. An intense violet band appeared at $419 \mathrm{~nm}$, originating from the stacking 
faults as well as the transition occurring from the conduction band to deep energy levels in the band gap related to $\mathrm{Zn}$ vacancies $[39,48]$. A blue emission at $469 \mathrm{~nm}$ was observed due to interstitial $\mathrm{Zn}$ (Zni) defects [47]. Large and relatively intense green bands are related to different ionized oxygen vacancies, i.e., $\mathrm{VO}^{+}, \mathrm{VO}^{++}$, and anti-site oxygen $\left(\mathrm{O}_{\mathrm{Zn}}\right)$ [47]. A typical yellow emission is also observed at $561 \mathrm{~nm}$. This is related to the interstitial oxygen sites $\mathrm{Oi}$, where its energy level is located at approximately $2.28 \mathrm{eV}$ from the conduction band [47]. Finally, the red emission observed here is induced by oxygen vacancies (VO) [47]. These peaks demonstrate the $\mathrm{Cr}$ doping effects on the emergence of various origins of defects in the $\mathrm{ZnO}$ host for undoped and $\mathrm{Cr}$ doped samples. From these emissions, any compound with a long PL lifetime will be interesting for photocatalysis application since the separation of electrons and holes will be easy.

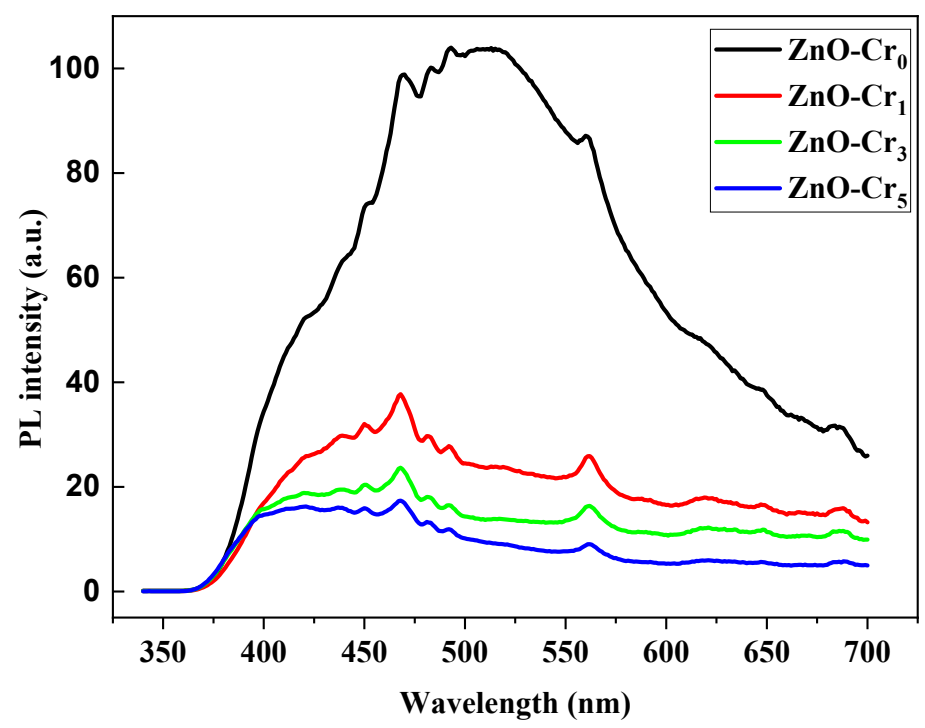

Figure 5. PL spectra of undoped and $\mathrm{Cr}$-doped $\mathrm{ZnO}$ nanorods using an He-Cd laser of $325 \mathrm{~nm}$ excitation wavelength.

\section{Photocatalytic Properties}

\subsection{Photocatalytic Activity of Methyl Orange}

The PCA of the synthesized Cr-doped ZnO samples was examined using UV-photode gradation of $\mathrm{MO}$ as a function of time. Figure 6 displays the variations in the concentration ratio $(\mathrm{C} / \mathrm{Co})$ as a function of time during the PCA reaction. Here, $\mathrm{C}$ and $\mathrm{Co}$ are the concentrations of the $\mathrm{MO}$ molecule at different times of reaction $(t)$ and $t=0$, respectively. This ratio refers to the photodegradation of the absorption band of $\mathrm{MO}$ positioned at $\sim 464 \mathrm{~nm}$ [11]. The $\mathrm{ZnO}-\mathrm{Cr}_{1}$ sample exhibited the best catalytic activity with degradation of $\mathrm{MO}$, where it reached $99.8 \%$ after $100 \mathrm{~min}$ of the reaction. The degradation of $\mathrm{MO}$ was about $77.5 \%, 58.97 \%$ and $50.1 \%$ after $120 \mathrm{~min}$ for the samples $\mathrm{ZnO}-\mathrm{Cr}_{0}, \mathrm{ZnO}_{-} \mathrm{Cr}_{3}$ and $\mathrm{ZnO}-\mathrm{Cr}_{5}$, correspondingly. Here, the high PCA observed for the $\mathrm{ZnO}-\mathrm{Cr}_{1}$ sample could be assigned to a possible high-density defect in the nanorods' structure $[49,50]$. This increases the density of the photoinduced electron traps [51]. 


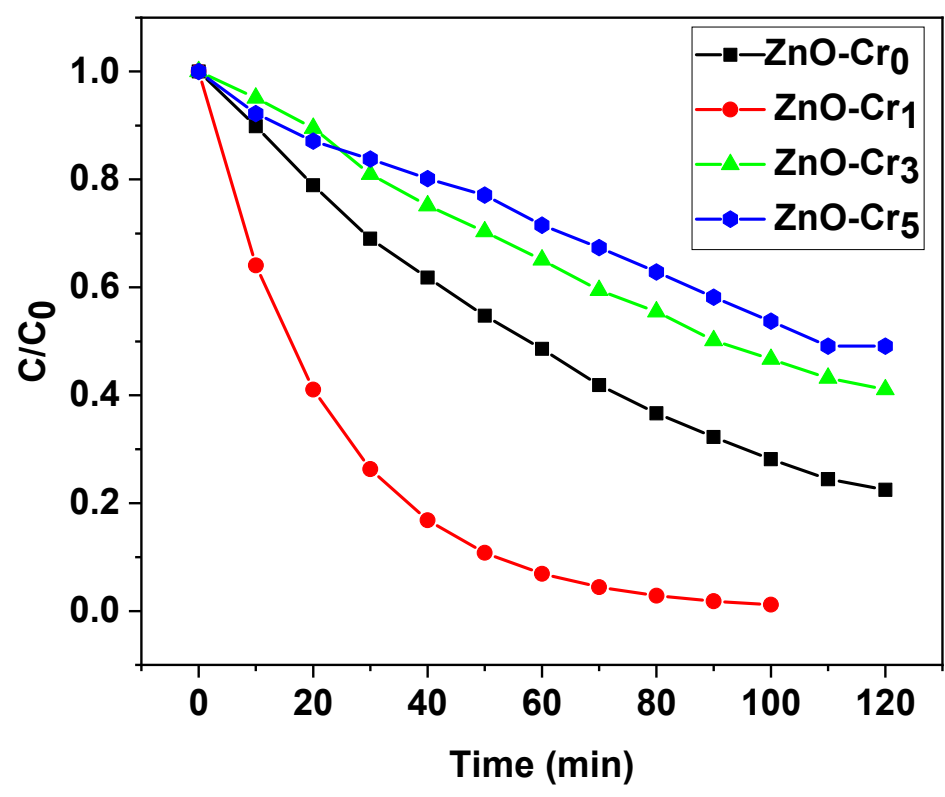

Figure 6. Photodegradation of $\mathrm{MO}, 10 \mathrm{ppm}$ in aqueous solution, performed under UV irradiation in the presence of the synthesized $\mathrm{Cr}$-doped $\mathrm{ZnO}$ nanorods.

The photodegradation time is quite long even for the $\mathrm{ZnO}^{-\mathrm{Cr}_{1}}$ sample (100 min to obtain $99.8 \%$ degradation). We studied the PCA reaction without adding any promotion factor for the reaction such as the addition of hydrogen peroxide $\left(\mathrm{H}_{2} \mathrm{O}_{2}\right)$ or even adjusting the $\mathrm{pH}$ value of the reaction. Indeed, the use of $\mathrm{H}_{2} \mathrm{O}_{2}$ could increase the $\bullet \mathrm{OH}$ radicals in the reaction where they react with dye molecules (i.e., $\mathrm{MO}$ ) to become a major factor in the degradation process [19]. In addition, controlling the acidic level ( $\mathrm{pH}$ value) has a significant effect on the degradation process parameters. It provides a fast decomposition of the $\mathrm{H}_{2} \mathrm{O}_{2}$, and also removes the formed inorganic elements derived from the decomposition of the dye molecule [22]. Here, we limited our study to the effect of photocatalytic nanorods, without adding any catalytic factors, i.e., $\mathrm{H}_{2} \mathrm{O}_{2}$ and $\mathrm{pH}$ level, on the photodegradation reaction. This allowed us to avoid any hazardous effect on the environment. Thus, we designed sample prototypes that could be used in eco-friendly photocatalytic reactions.

\subsection{Kinetic Study of Photocatalytic Degradation of $M O$}

As shown in Figure 7, the experimental data are well described with the pseudofirst order kinetic law [21] since the curves of $\operatorname{Ln}\left(A_{0} / A\right)$ versus irradiation time are well adjusted with linear fitting. The $\mathrm{ZnO}-\mathrm{Cr}_{1}$ photocatalyst was the most effective with a kinetic rate constant $\mathrm{k}$ of $4.451 \times 10^{-2} \mathrm{~min}^{-1}$ for the photodegradation of MO. The other photocatalysts are less effective and the calculated constant $\mathrm{k}$ estimated for the $\mathrm{ZnO}$, $\mathrm{ZnO}-\mathrm{Cr}_{3}$ and $\mathrm{ZnO}-\mathrm{Cr}_{5}$ photocatalysts, respectively, was $1.274 \times 10^{-2}, 0.775 \times 10^{-2}$ and $0.608 \times 10^{-2} \mathrm{~min}^{-1}$. 


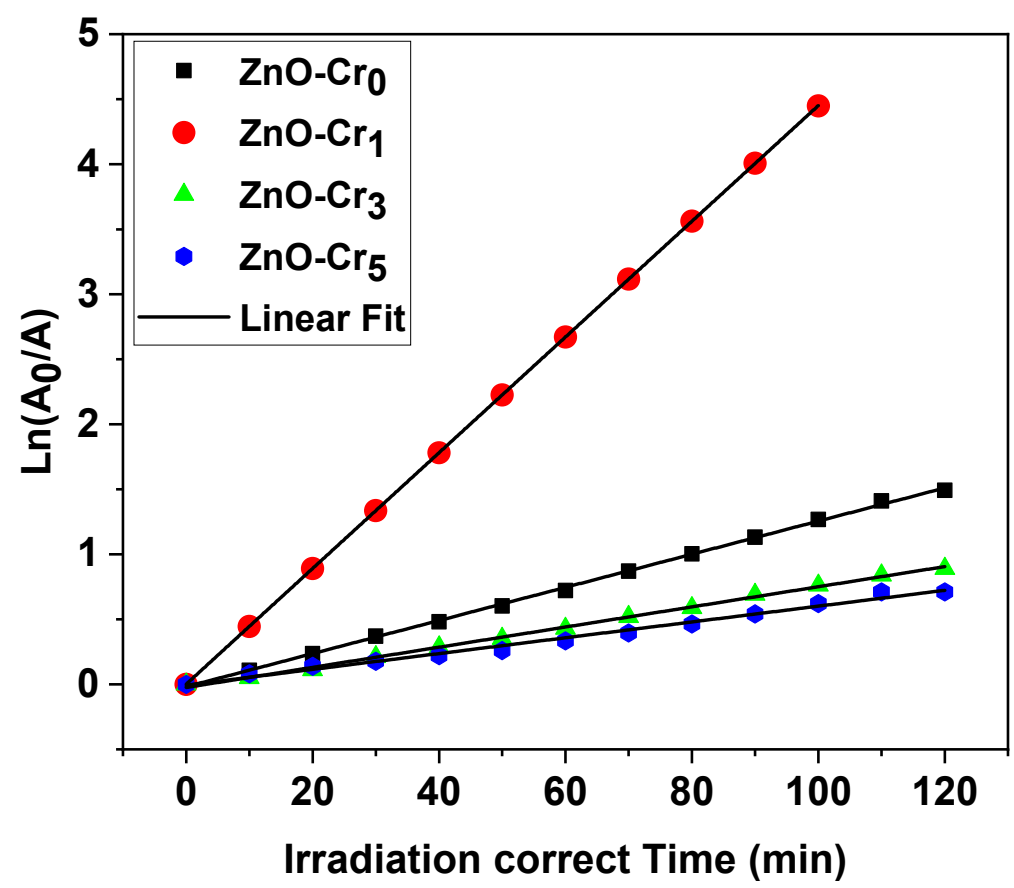

Figure 7. Kinetic study of the photocatalytic degradation of $\mathrm{MO}, 10 \mathrm{ppm}$ in aqueous solution, using Cr-doped $\mathrm{ZnO}$ nanorods.

\subsection{Mechanism of the Photocatalytic Activity}

The photocatalytic activity (PAC) of the synthesized Cr-doped ${ }^{\mathrm{ZnO}}$ nanorods was inspected under UV-vis irradiation. During this process, the photocatalyst absorbs the irradiated light to generate electron hole $\left(\mathrm{e}-/ \mathrm{h}^{+}\right)$pairs. Indeed, the irradiation on its surface may have an equal or higher energy than the studied $\mathrm{Cr}$-doped $\mathrm{ZnO}$ nanorods band gap resulting in $\left(\mathrm{e}^{-} / \mathrm{h}^{+}\right)$pairs. A new charge redistribution appears where the generated $\left(\mathrm{e}^{-} / \mathrm{h}^{+}\right)$ pairs are on the photocatalyst surface. This will free the methyl orange (MO) molecules via a redox reaction. The effect of dopant concentration is very important in describing PAC. Different rates of the MO degradation for various time intervals under light irradiation were noticed. In particular, good degradation was observed for the pure $\mathrm{ZnO}$ sample, i.e., $\mathrm{ZnO}-\mathrm{Cr}_{0}$. This is related to excitation $\lambda<390 \mathrm{~nm}$, which generates electron-hole pairs in $\mathrm{ZnO}$ photocatalysts [52]. These electron-hole pairs on the surface of the photocatalyst pass through a series of oxidation-reduction reactions affecting the aromatic rings of the $\mathrm{MO}$ molecules. This results in degradation of $\mathrm{MO}$ for the case of $\mathrm{ZnO}-\mathrm{Cr}_{0}$. However, specific $\mathrm{ZnO}$ catalysts showed effective degradation compared to $\mathrm{ZnO}-\mathrm{Cr}_{0}$. $\mathrm{ZnO}-\mathrm{Cr}_{1}$ showed a maximum degradation efficiency of $99.8 \%$ of the $\mathrm{MO}$ in $100 \mathrm{~min}$. Here, the photocatalytic process involves an advanced chemical reaction, ensuring MO degradation, as denoted above. The generated holes in the valence band of the $\mathrm{Cr}$-doped $\mathrm{ZnO}$ nanorods can react with surface $\mathrm{OH}$ - groups to yield the highly reactive hydroxyl radical $(\mathrm{OH} \bullet)$. At the same time, electrons remaining from the $(\mathrm{e}-\mathrm{h}+\mathrm{h})$ pair will interfere with local oxygen adsorbed at the surface of the nanoparticles and produce the superoxide $\left(\mathrm{O}_{2}^{--}\right)$. Therefore, as oxygen vacancies increase, better absorption of $\mathrm{O}_{2}$ will occur. $\mathrm{O}_{2}$ is also converted into superoxide radicals $\left(\mathrm{O}_{2}^{\bullet-}\right)$ through its interaction with the photoinduced electrons on oxygen defects via an ionisation process [53]. These $\mathrm{O}_{2}^{--}$and $\mathrm{OH} \bullet$ oxidizing radicals decompose and mineralize the adsorbed organic compounds into $\mathrm{CO}_{2}, \mathrm{H}_{2} \mathrm{O}$ and different minerals. Such a complex chemical process ensures a proper photodegradation of the methyl orange molecule bonded to $\mathrm{Cr}$-doped $\mathrm{ZnO}$ nanorods [54,55]. In addition, the local $\mathrm{Cr}^{2+}$ ions reinforce the interstitial oxygen defect effect, where they trap electrons and separate the charges to prevent their recombination. Nevertheless, $\mathrm{ZnO}_{-} \mathrm{Cr}_{3}$ and $\mathrm{ZnO}^{-\mathrm{Cr}_{5}}$ display opposite photodegradation responses despite the increase in the dopant concentration. The degradation efficiency reached $58.97 \%$ and $50.1 \%$, respectively, for $\mathrm{ZnO}^{-} \mathrm{Cr}_{3}$ and $\mathrm{ZnO}^{-} \mathrm{Cr}_{5}$ 
after $120 \mathrm{~min}$. Such a reduction could be related to the increased density of $\mathrm{Cr}$ interstitials compared to the $\mathrm{Cr}$ substitutional in the $\mathrm{ZnO}$ lattice, which will act as recombination centers for the photogenerated $\mathrm{e}-/ \mathrm{h}+$ pairs and, consequently, reduce the generation process of $\mathrm{OH} \bullet$ and $\mathrm{O}_{2}^{\bullet-}$ radicals [43]. Thus, $\mathrm{ZnO}_{-} \mathrm{Cr}_{1}$ is the optimal doping giving the best photodegradation efficiency of $\mathrm{MO}$ compared to the other synthesized catalysts.

\subsection{Change of Reaction Rate in the Presence and Absence of a Quenching Agent}

To clarify the major active species in the photodegradation process, we used the trapping experiments to investigate the change in the photodegradation rate. For this purpose, $10 \%$ of ethanol and benzoquinone were added separately into the reaction system to quench the $\mathrm{OH} \bullet$ radicals and $\mathrm{O}_{2}^{\bullet-}$ superoxides, respectively. As shown in Figure 8, the addition of ethanol induced a slight reduction in the photodegradation (up to 20\%), indicating that the photoexcited holes of the photocatalyst and the subsequent $\mathrm{OH} \bullet$ radicals are minor factors. However, a relatively large reduction in the dye photodegradation (up to $46 \%$ ) in the presence of BQ agent demonstrated superoxide quenching and established that the $\mathrm{O}_{2}^{\bullet-}$ superoxide is the main active species for the dye photodegradation in the presence of the $\mathrm{ZnO}^{-\mathrm{Cr}_{1}}$ photocatalyst.

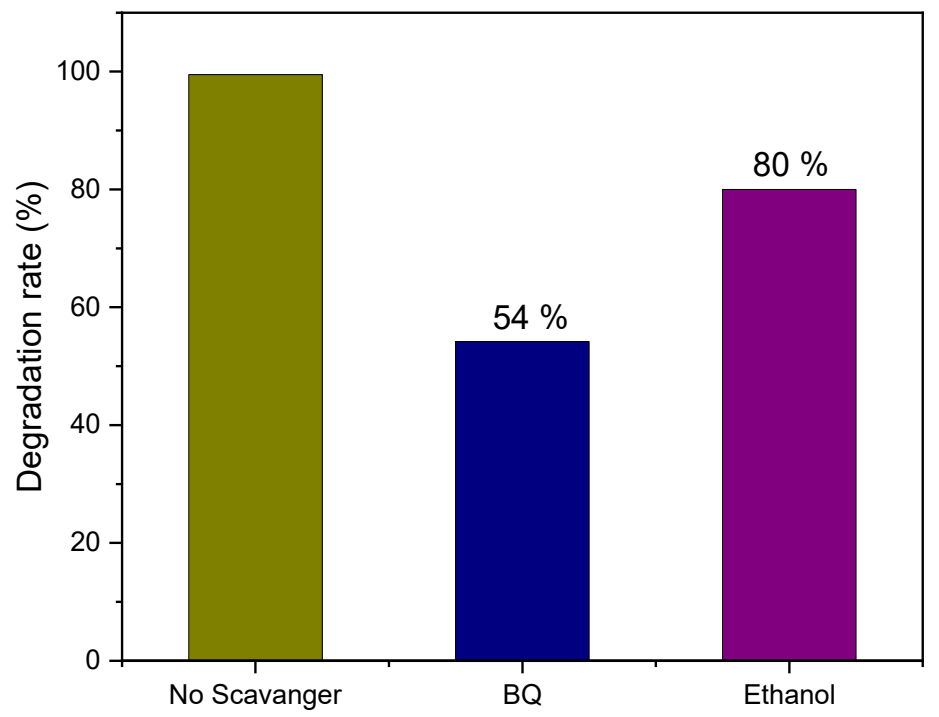

Figure 8. Change in the reaction rate in the presence and absence of a quenching agent.

The various entities composing the mixture undergo various reactions under UVvisible irradiation (Figure 9). These reactions can be summarized as follows:

$$
\begin{gathered}
\mathrm{ZnO}+\mathrm{hv} \rightarrow \mathrm{ZnO}\left(\mathrm{e}^{-}+\mathrm{h}^{+}\right) \\
\mathrm{e}^{-}+\mathrm{O}_{2} \rightarrow \mathrm{O}_{2}^{\bullet-} \\
\mathrm{h}^{+}+\mathrm{H}_{2} \mathrm{O} \rightarrow \mathrm{OH} \bullet+\mathrm{H}^{+} \\
\mathrm{O}_{2}^{\bullet-} / \mathrm{OH} \bullet+\text { Methyl Orange } \rightarrow \mathrm{CO}_{2}+\mathrm{H}_{2} \mathrm{O}
\end{gathered}
$$




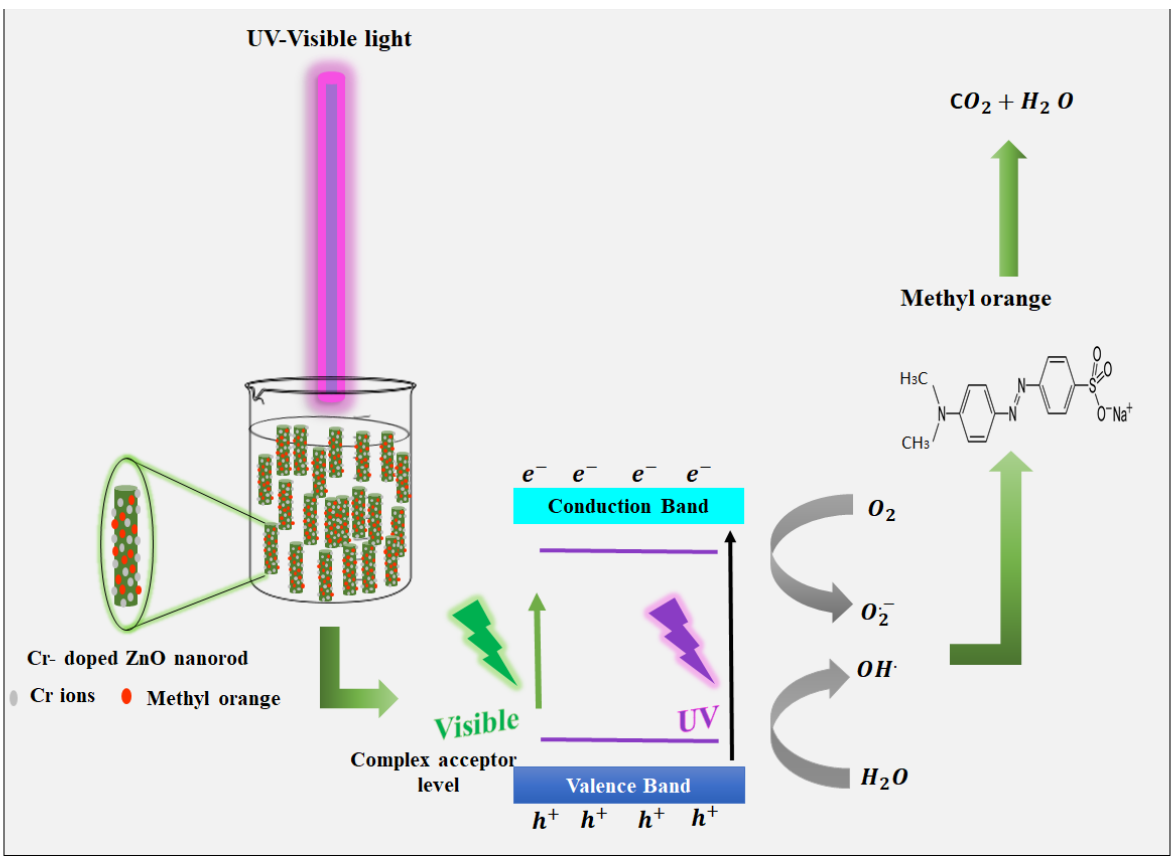

Figure 9. Photocatalytic mechanism for Cr-doped $\mathrm{ZnO}$ nanorods under UV-visible light.

Under visible light irradiation, it is anticipated that such levels appearing among those detected by PL could be the origin of the observed improvement in the photocatalytic activity of modified $\mathrm{ZnO}$ nanorods. Actually, the interstitial oxygen site $\mathrm{O}_{\mathrm{i}}$ is the dominant defect observed at $2.28 \mathrm{eV}$, and it could act as a deep donor with an energy level located at $2.28 \mathrm{eV}$, above the top of the valence band. Therefore, the energy position of $\mathrm{O}_{\mathrm{i}}$ is optimal for the generation of holes in the valence band under visible irradiation (less than 2.95 $\mathrm{eV})$. The created holes can systematically help the photodegradation of RhB through the following reaction:

$$
\begin{gathered}
\mathrm{O}_{\mathrm{i}}^{+}+\mathrm{e}^{-} \stackrel{\mathrm{h} v<2.95 \mathrm{eV}}{\rightarrow} \mathrm{O}_{\mathrm{i}}+\mathrm{h}^{+} \\
\mathrm{H}_{2} \mathrm{O}+\mathrm{h}^{+} \rightarrow \mathrm{OH}^{\bullet}+\mathrm{H}^{+}
\end{gathered}
$$

It is worth noting that a direct interaction between $\mathrm{MO}$ dye and light could transform $\mathrm{MO}$ to $\mathrm{MO}^{*}$ excited. Thus, $\mathrm{MO}^{*}$ excited can transfer electrons to the conduction band (or a surface state) of $\mathrm{ZnO}$ nanorods. Finally, two pathways are feasible: the injected electrons react with $\mathrm{O}_{2}$ molecules adsorbed on the $\mathrm{ZnO}$ surface to yield $\mathrm{O}_{2}^{\bullet-}$ radical anion, while $\mathrm{h}^{+}$ in $\mathrm{VB}$ moves to the backside of the $\mathrm{ZnO}$ nanorods' surface and reacts with either $\mathrm{H}_{2} \mathrm{O}$ or $\mathrm{OH}^{-}$to produce an active species such as $\mathrm{OH}$ radicals; or mineralization of $\mathrm{MO}$ takes place through the reaction of the active species, which could be considered a very efficient way to degrade $\mathrm{MO}$.

\subsection{Temperature Effect}

We studied the temperature effect on the photodegradation of MO. Figure 10 shows the variation of $\mathrm{C} / \mathrm{Co}$ with time of the photocatalytic reaction for the $\mathrm{ZnO}-\mathrm{Cr}_{1}$ sample at room temperature (RT) and at $45^{\circ} \mathrm{C}$. Here, PCA decreased with increasing temperature, as did the degradation percentage of $\mathrm{MO}$. The latter reached $53 \%$ at $45^{\circ} \mathrm{C}$ after $100 \mathrm{~min}$, which is lower than that obtained after the same time at RT $(\approx 98.8 \%)$. This dramatic detraction is mainly due to less adsorption of dye molecules on the surface of the photocatalyst. In fact, when the temperature increases, the exothermic adsorption of reactants becomes disfavored, thus limiting the photodegradation reaction [56]. In addition, with increasing temperatures, the enhanced kinetic energy of dye molecules might allow them to escape from the photocatalyst surface [24], leading to decreased photodegradation efficiency. On the other hand, it is known that for semiconductor photocatalysts like $\mathrm{ZnO}$, the PL 
intensity decreases with increasing temperature due to the dissociation of excitons (thermal quenching), which also leads to less generation of electrons and holes that contribute to the creation of an $\mathrm{OH} \bullet$ radical and $\mathrm{O}_{2}^{\bullet-}$ superoxide. Therefore, a limitation of the photodegradation process is obtained.

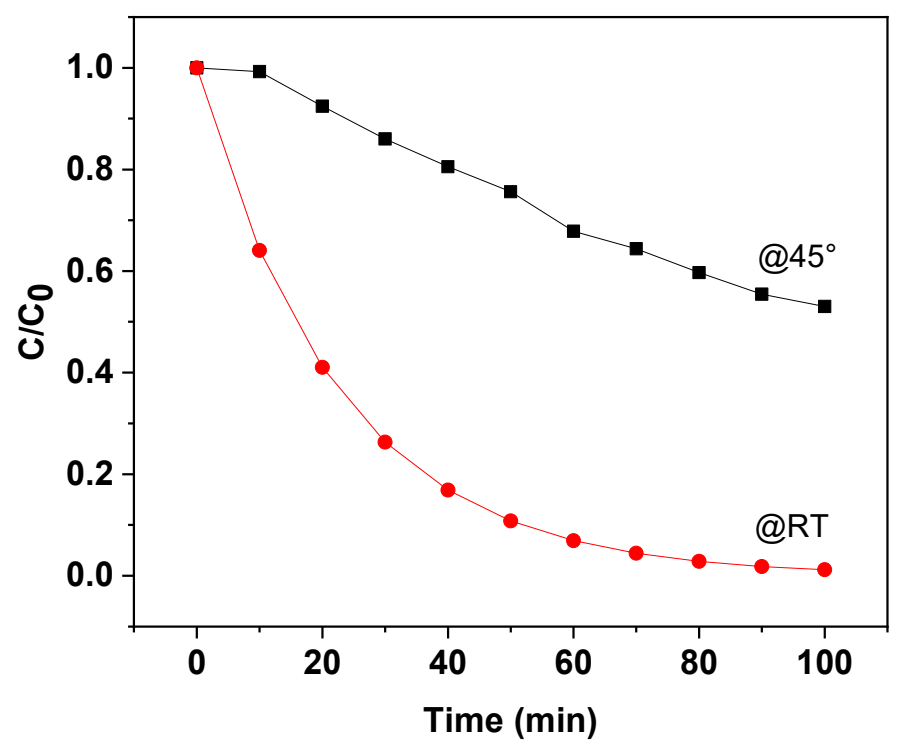

Figure 10. Temperature effect on the photodegradation of $\mathrm{MO}, 10 \mathrm{ppm}$ in aqueous solution, performed under irradiation using the $\mathrm{ZnO}^{-\mathrm{Cr}_{1}}$ sample.

\subsection{MO Concentration Dependency of the Photodegradation}

The removal efficiency is significantly affected by the initial concentration of the pollutant [25]. In this respect, we compared the photodegradation levels for different initial MO concentrations ranging from $5 \mathrm{ppm}$ to $30 \mathrm{ppm}$ with a constant $\mathrm{ZnO}-\mathrm{Cr}_{1}$ sample concentration of $20 \mathrm{mg} / \mathrm{L}$ (Figure 11). The photocatalytic activity decreased with increasing initial concentrations of MO. The recorded removal percentages of MO after $30 \mathrm{~min}$ were $100 \%$, $77 \%, 37.7 \%$, and $23.9 \%$ for the initial concentrations of $5,10,20$ and $30 \mathrm{ppm}$, respectively.

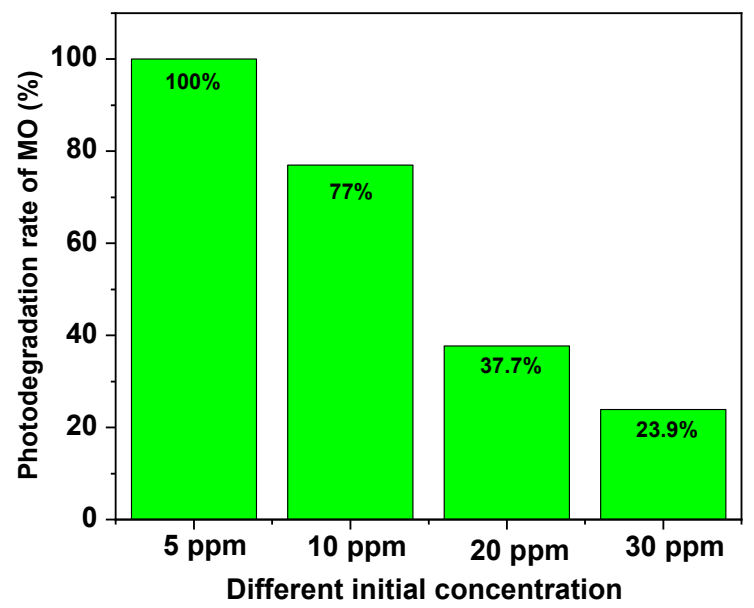

Figure 11. Photodegradation of MO at different initial concentrations after $30 \mathrm{~min}$ under UV irradia-

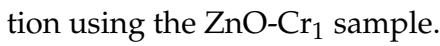

\subsection{Study of the Photocatalyst Stability}

A recycle experiment was used to inspect the photostability of the photocatalyst, as

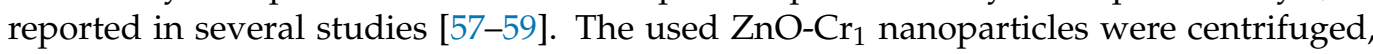
washed and then dried for the next experiment. As shown in Figure 12, even after five 


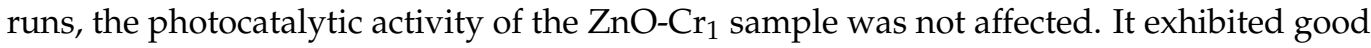
performance and stability during all runs. These results suggest high recyclability of the $\mathrm{ZnO} \mathrm{Cr}_{1}$ photocatalyst and its reusability for the photodegradation of organic pollutants under visible light irradiation.

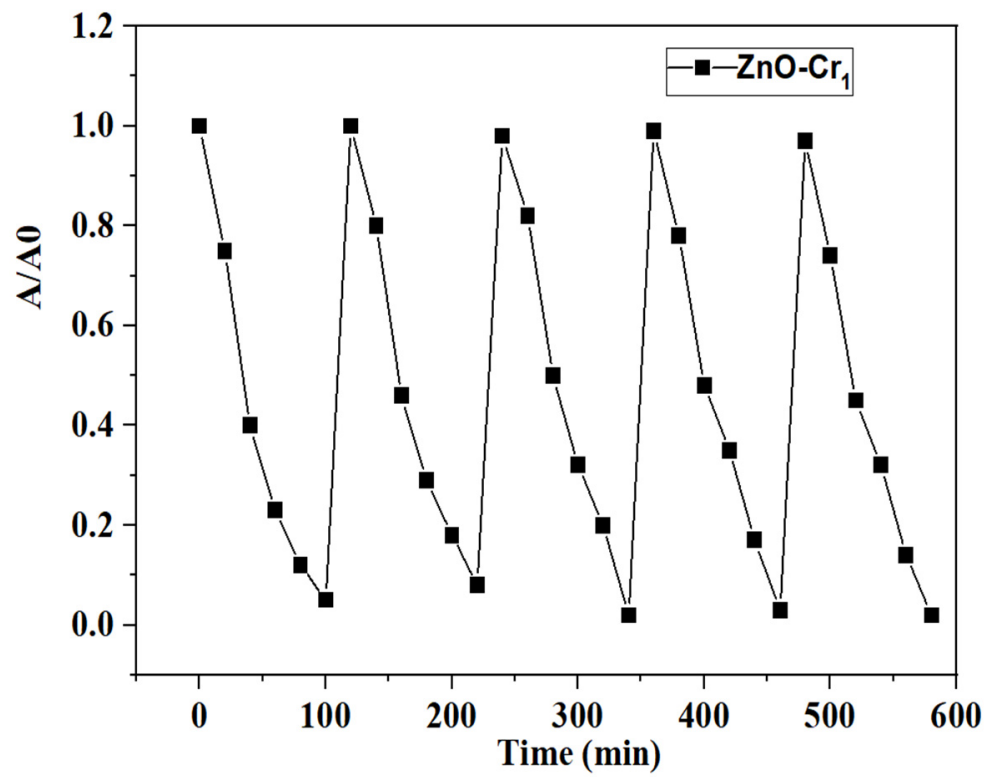

Figure 12. Stability experiment in the presence of $\mathrm{ZnO}-\mathrm{Cr}_{1}$.

Motivated by the $\mathrm{ZnO}-\mathrm{Cr}_{1}$ photocatalyst answer, we investigated its photo effect

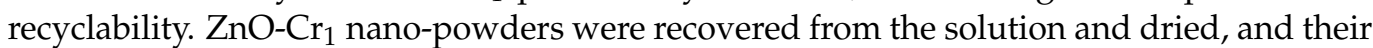
XRD patterns were measured. The latter were almost identical to the XRD pattern of the

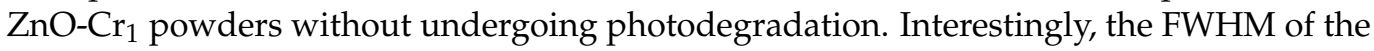
peaks were not changed (Figure 13). This demonstrates how the photocatalyst crystallinity is unchanged after 5 (cycles) runs, establishing its high stability and reusability.

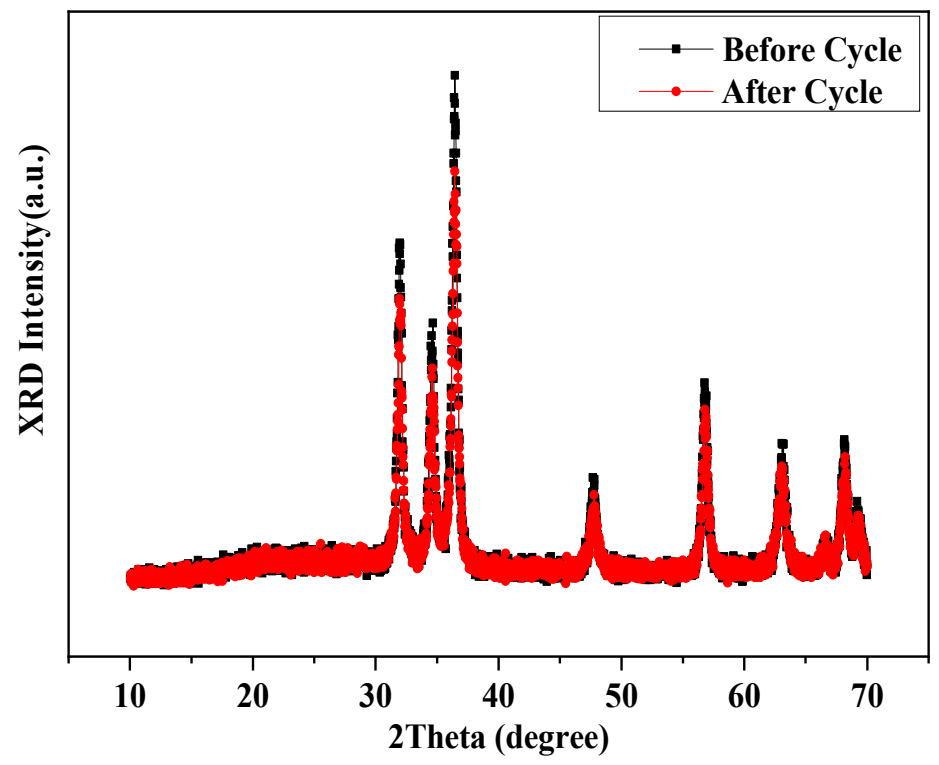

Figure 13. $\mathrm{XRD}$ of $\mathrm{ZnO}-\mathrm{Cr}_{1}$ before and after the cycling experiment.

\section{Conclusions}

The optical and morphological characterizations confirmed the stability of the host structure, i.e., $\mathrm{ZnO}$ after exchanging $\mathrm{Zn}^{2+}$ ions with $\mathrm{Cr}^{3+}$ ions. The synthesized $\mathrm{Cr}$-doped 
$\mathrm{ZnO}$ nanorods, synthesized using a thermal decomposition technique, were introduced as photocatalyst materials. The $\mathrm{ZnO}-\mathrm{Cr}_{1}$ sample exhibited promising results in the photocatalysis process with $\mathrm{MO}$ removal and showed good stability and reusability. The $\mathrm{O}_{2}^{\bullet-}$ superoxide was identified as the main active species for the dye photodegradation. An increase in temperature had an adverse effect on the studied photocatalysis process that was attributed to the enhancement of the activity of the surface area of the synthesized nanorod. This resulted in a decrease in the adsorption of MO molecules. This study opens the door to functionalization of $\mathrm{Cr}$-doped $\mathrm{ZnO}$ nanorods for future optoelectronic application.

Author Contributions: Conceptualization, F.H.A., A.B.G.T.; investigation, F.H.A., A.B.G.T., R.N., H.E.; formal analysis, S.F., R.N., J.-M.S.; methodology, F.H.A., A.B.G.T., R.N., H.E.; data curation, A.B.G.T., R.N., S.F., J.-M.S.; writing—original draft preparation, F.H.A., A.B.G.T.; writing-review and editing, F.H.A., A.B.G.T., H.E.; supervision H.E., J.-M.S. All authors have read and agreed to the published version of the manuscript.

Funding: This research was funded by Princess Nourah bint Abdulrahman University Researchers Supporting Project number (PNURSP2022R38), Princess Nourah bint Abdulrahman University, Riyadh, Saudi Arabia.

Institutional Review Board Statement: Not applicable.

Informed Consent Statement: Not applicable.

Acknowledgments: This research was funded by Princess Nourah bint Abdulrahman University Researchers Supporting Project number (PNURSP2022R38), Princess Nourah bint Abdulrahman University, Riyadh, Saudi Arabia.

Conflicts of Interest: The authors declare no conflict of interest.

\section{References}

1. Karimi-Maleh, H.; Kumar, B.G.; Rajendran, S.; Qin, J.; Vadivel, S.; Durgalakshmi, D.; Gracia, F.; Soto-Moscoso, M.; Orooji, Y.; Karimi, F. Tuning of metal oxides photocatalytic performance using Ag nanoparticles integration. J. Mol. Liq. 2020, $314,113588$. [CrossRef]

2. Saravanan, R.; Thirumal, E.; Gupta, V.; Narayanan, V.; Stephen, A. The photocatalytic activity of ZnO prepared by simple thermal decomposition method at various temperatures. J. Mol. Liq. 2013, 177, 394-401. [CrossRef]

3. Liu, H.-L.; Zhou, D.; Li, X.-Z.; Yue, P.-T. Photoelectrocatalytic degradation of rose Bengal. J. Environ. Sci. $2003,15,595$.

4. Agustina, T.E.; Ang, H.M. Decolorization and mineralization of CI reactive blue 4 and CI reactive red 2 by Fenton oxidation process. Int. J. Chem. Environ. Eng. 2012, 3, 141.

5. Soria, J.; Conesa, J.C.; Augugliaro, V.; Palmisano, L.; Schiavello, M.; Sclafani, A. Dinitrogen photoreduction to ammonia over titanium dioxide powders doped with ferric ions. J. Phys. Chem. Solids 1991, 95, 274. [CrossRef]

6. Choi, W.; Termin, A.; Hoffmann, M.R. The Role of Metal Ion Dopants in Quantum-Sized TiO 2 : Correlation between Photoreactivity and Charge Carrier Recombination Dynamics. J. Phys. Chem. Solids 1994, 98, 13669. [CrossRef]

7. Tanimoto, T.; Suekuni, K.; Tanishita, T.; Usui, H.; Tadano, T.; Kamei, T.; Saito, H.; Nishiate, H.; Lee, C.H.; Kuroki, K.; et al. Enargite Cu3PS4: A Cu-S-Based Thermoelectric Material with a Wurtzite-Derivative Structure. Adv. Funct. Mater. 2020, $30,2000973$. [CrossRef]

8. Jing, L.; Qu, Y.; Wang, B.; Li, S.; Jiang, B.; Yang, L.; Fu, W.; Fu, H.; Sun, J. Review of photoluminescence performance of nano-sized semiconductor materials and its relationships with photocatalytic activity. Sol. Energy Mater. Sol. Cells 2006, 90, 1773.

9. Sreekanth, M.; Ghosh, S.; Mehta, S.K.; Ganguli, A.K.; Jha, M. Investigation of the growth mechanism of the formation of ZnO nanorods by thermal decomposition of zinc acetate and their field emission properties. CrystEngComm J. 2017, 19, 2264-2270.

10. Saravanan, R.; Santhi, K.; Sivakumar, N.; Narayanan, V.; Stephen, A. Synthesis and characterization of ZnO and Ni doped ZnO nanorods by thermal decomposition method for spintronics application. Mater. Charact. 2012, 67, 10. [CrossRef]

11. Lkallas, F.H.A.; Elshokrofy, K.M.; Mansour, S.A. Structural and diffuse reflectance characterization of cobalt-doped titanium dioxide nanostructured powder prepared via facile sonochemical hydrolysis technique. J. Inorg. Organomet. Polym. Mat. 2019, 29, 792. [CrossRef]

12. Meng, A.; Xing, J.; Li, Z.; Li, Q. Cr-doped ZnO nanoparticles: Synthesis, characterization, adsorption property, and recyclability. ACS Appl. Mat. Interf. 2015, 7, 27449. [CrossRef]

13. Tony, M.; Mansour, S.A. Removal of the commercial reactive dye Procion Blue MX-7RX from real textile wastewater using the synthesized $\mathrm{Fe}_{2} \mathrm{O}_{3}$ nanoparticles at different particle sizes as a source of Fenton's reagent. Int. J. Environ. Sci. Technol. 2020, 17, 709-720. [CrossRef]

14. Liu, C.; Yang, Z.; Li, Q.; Guo, K. A two-step continuous synthesis of $\alpha$-ketoamides and $\alpha$-amino ketones from $2^{\circ}$ benzylic alcohols using hydrogen peroxide as an economic and benign oxidant. RSC Adv. 2016, 6, 25167. [CrossRef] 
15. Farha, A.H.; Mansour, S.A.; Kotkata, M.F. Synthesis and Study of ZnO Nanoparticles by Polymer Pyrolysis Route Using Two Different Polymerization Initiators. J. Mater. Sci. 2016, 51, 9855. [CrossRef]

16. Han, J.; Fan, F.; Xu, C.; Lin, S.; Wei, M.; Duan, X.; Wang, Z.L. ZnO nanotube-based dye-sensitized solar cell and its application in self-powered devices. Nanotechnology 2010, 21, 405203. [CrossRef]

17. Bousslama, W.; Sieber, B.; Elhouichet, H.; Gelloz, B.; Addad, A.; Ferid, M. Enhancement of the intensity ratio of ultraviolet to visible luminescence with increased excitation in $\mathrm{ZnO}$ nanoparticles deposited on porous anodic alumina. J. Phys. D Appl. Phys. 2013, 46, 1-8. [CrossRef]

18. Othmen, W.B.H.; Ben Ali, M.; Bouslama, W.; Elhouichet, H. Solar driven photocatalytic properties of Sm3+ doped ZnO nanocrystals. Ceram. Int. 2020, 46, 18878. [CrossRef]

19. Mansour, S.A. Non-isothermal crystallization kinetics of nano-sized amorphous $\mathrm{TiO}_{2}$ prepared by facile sonochemical hydrolysis route. Ceram. Int. 2019, 45, 2893-2898. [CrossRef]

20. Abed, C.; Ali, M.B.; Addad, A.; Elhouichet, H. Processing and Study of Optical and Electrical Properties of (Mg, Al) Co-Doped ZnO Thin Films Prepared by RF Magnetron Sputtering for Photovoltaic Application. Mat. Res. Bull. 2019, 110, 230-238. [CrossRef]

21. Martinz, N.S.; Fernandez, J.F.; Segura, X.F.F.; Ferrer, A.S. Pre-oxidation of an extremely polluted industrial wastewater by the Fenton's reagent. J. Hazard. Mater. B 2003, 101, 315.

22. Buxton, G.V.; Greenstock, C.L.; Helman, W.P.; Ross, A.B. Critical Review of rate constants for reactions of hydrated electrons, hydrogen atoms and hydroxyl radicals $(\cdot \mathrm{OH} / \cdot \mathrm{O}-$ in Aqueous Solution. J. Phys. Chem. 1988, 17, 513. [CrossRef]

23. Lin, C.-C.; Li, Y.-Y. Synthesis of ZnO nanowires by thermal decomposition of zinc acetate dihydrate. Mater. Chem. Phys. 2009, 113, 334-337. [CrossRef]

24. Barakat, N.; Kanjwal, M.; Chronakis, I.; Kim, H. Influence of temperature on the photodegradation process using Ag-doped TiO 2 nanostructures: Negative impact with the nanofibers. J. Mol. Catal. A Chem. 2013, 366, 333. [CrossRef]

25. Najjar, W.; Chirchi, L.; Santosb, E.; Ghorhel, A. Kinetic study of 2-nitrophenol photodegradation on Al-pillared montmorillonite doped with copper. J. Environ. Monit. 2001, 3, 697. [CrossRef]

26. Pearton, S.J.; Norton, D.P.; Heo, Y.W.; Tien, L.C.; Ivill, M.P.; Li, Y.; Kang, B.S.; Ren, F.; Kelly, J.; Hebard, A.F. ZnO spintronics and nanowire devices. J. Electron. Mater. 2006, 35, 5. [CrossRef]

27. Yang, Y.; Li, X.; Chen, J.; Chen, H.; Bao, X. ZnO nanoparticles prepared by thermal decomposition of $\beta$-cyclodextrin coated zinc acetate. Chem. Phys. Lett. 2003, 373, 22-27. [CrossRef]

28. Chen, X.; Wu, Z.; Liu, D.; Gao, Z. Preparation of ZnO Photocatalyst for the Efficient and Rapid Photocatalytic Degradation of Azo Dyes. Nanoscale Res. Lett. 2017, 12, 143. [CrossRef]

29. Liu, D.D.; Wu, Z.S.; Tian, F.; Ye, B.C.; Tong, Y.B. Synthesis of $\mathrm{N}$ and La co-doped $\mathrm{TiO}_{2} / \mathrm{AC}$ photocatalyst by microwave irradiation for the photocatalytic degradation of naphthalene. J. Alloys. Compd. 2016, 676, 489-498. [CrossRef]

30. Othmen, W.B.H.; Hamdi, A.; Addad, A.; Sieber, B.; Elhouichet, H.; Szunerits, S.; Boukherroub, R. Fe-doped SnO 2 decorated reduced graphene oxide nanocomposite with enhanced visible light photocatalytic activity. Mater. Res. Bull. 2016, 83, 481-490. [CrossRef]

31. Cižmar, T.; Kojic, V.; Rukavina, M.; Brkljacic, L.; Salamon, K.; Grcic, I.; Radetic, L.; Gajovic, A. Hydrothermal Synthesis of FeOOH and $\mathrm{Fe}_{2} \mathrm{O}_{3}$ Modified Self-Organizing Immobilized $\mathrm{TiO}_{2}$ Nanotubes for Photocatalytic Degradation of $1 \mathrm{H}$-Benzotriazole. Catalysts 2020, 10, 1371. [CrossRef]

32. Ali, M.B.; Barras, A.; Addad, A.; Sieber, B.; Elhouichet, H.; Ferid, M.; Szunerits, S.; Boukherroub, R. $\mathrm{Co}_{2} \mathrm{SnO}_{4}$ nanoparticles as a high performance catalyst for oxidative degradation of rhodamine B dye and pentachlorophenol by activation of peroxymonosulfate. Phys. Chem. Chem. Phys. 2017, 19, 6569. [CrossRef] [PubMed]

33. Nasser, R.; Elhouichet, H.; Ferid, M. Effect of Mn doping on structural, optical and photocatalytic behaviors of hydrothermal Zn 1-x Mn x S nanocrystals. Appl. Surf. Sci. 2015, 351, 1122-1130. [CrossRef]

34. Bousslama, W.; Elhouichet, H.; Férid, M. Enhanced photocatalytic activity of Fe doped ZnO nanocrystals under sunlight irradiation. Optik 2017, 134, 88-98.

35. Ansari, S.A.; Khan, M.M.; Ansari, M.O.; Lee, J.; Cho, M.H. Biogenic synthesis, photocatalytic, and photoelectrochemical performance of Ag-ZnO nanocomposite. J. Phys. Chem. C 2013, 117, 27023-27030. [CrossRef]

36. Molefe, F.V.; Koao, L.F.; Dejene, B.F.; Swart, H.C. Phase formation of hexagonal wurtzite $\mathrm{ZnO}$ through decomposition of $\mathrm{Zn}(\mathrm{OH})_{2}$ at various growth temperatures using CBD method. Opt. Mater. 2015, 46, 292-298. [CrossRef]

37. Nasser, R.; Othmen, W.B.H.; Elhouichet, H.; Férid, M. Preparation, characterization of Sb-doped ZnO nanocrystals and their excellent solar light driven photocatalytic activity. Appl. Surf. Sci. 2017, 393, 486-495. [CrossRef]

38. Asadabad, M.A.; Eskandari, M.J.; Diffraction, E. Modern Electron Microscopy in Physical and Life Sciences; Milos, J., Robert, K., Eds.; Intech Open: London, UK, 2016.

39. Nasser, R.; Elhouichet, H. Production of acceptor complexes in sol-gel ZnO thin films by Sb doping. J. Lumin. 2018, 196, 11-19. [CrossRef]

40. Nasser, R.; Song, J.; Elhouichet, H. Epitaxial growth and properties study of p-type doped ZnO:Sb by PLD. Superlattices Microstruct. 2021, 155, 106908. [CrossRef]

41. Huang, W.; Cai, J.; Hu, J.; Zhu, J.; Yang, F.; Bao, X. Atomic structures and electronic properties of Cr-doped ZnO surfaces. Chin. J. Catal. 2021, 42, 971-979. [CrossRef] 
42. Yılmaz, S.; Parlak, M.; Özcanc, S.; McGlynn, M.A.E.; Bacaksı, E. Structural, optical and magnetic properties of Cr doped ZnO microrods prepared by spray pyrolysis method. Appl. Surf. Sci. 2011, 257, 9293-9298. [CrossRef]

43. Tabib, A.; Bouslama, W.; Sieber, B.; Addad, A.; Elhouichet, H.; Férid, M.; Boukherroub, R. Structural and optical properties of Na doped ZnO nanocrystals: Application to solar photocatalysis. Appl. Surf. Sci. 2017, 396, 1528-1538. [CrossRef]

44. Manikandan, A.; Vijaya, J.J.; Narayanan, S.; Kennedy, L.J. Comparative investigation of structural, optical properties and dye-sensitized solar cell applications of ZnO nanostructures. J. Nanosci. Nanotechnol. 2014, 14, 2507. [CrossRef] [PubMed]

45. Manikandan, A.; Vijaya, J.J.; Ragupathi, C.; Kennedy, L.J. Optical properties and dye-sensitized solar cell applications of ZnO nanostructures prepared by microwave combustion synthesis. J. Nanosci. Nanotechnol. 2014, 14, 2584. [CrossRef] [PubMed]

46. Farha, A.H.; Mansour, S.A.; Kotkata, M.F. Ga-Doped ZnO Nanostructured Powder for Cool-Nanopigment in Environment Applications. Materials 2020, 13, 5152. [CrossRef]

47. Abed, C.; Fernandez, S.; Elhouichet, H. Studies of optical properties of $\mathrm{ZnO}: \mathrm{MgO}$ thin films fabricated by sputtering from home-made stable oversize targets. Optik 2020, 216, 164934. [CrossRef]

48. Koidl, P. Optical absorption of Co2+ in ZnO. Phys. Rev. B 1977, 15, 2493. [CrossRef]

49. Ghosh, A.; Deshpande, N.G.; Gudage, Y.G.; Joshi, R.A.; Sagade, A.A.; Phase, D.M.; Sharma, R. Effect of annealing on structural and optical properties of zinc oxide thin film deposited by successive ionic layer adsorption and reaction technique. J. Alloy. Compd. 2009, 469, 56. [CrossRef]

50. Zhang, X.; Qin, J.; Xue, Y.; Yu, P.; Zhang, B.; Wang, L.; Liu, R. Effect of aspect ratio and surface defects on the photocatalytic activity of ZnO nanorods. Sci. Rep. 2014, 4, 4596. [CrossRef] [PubMed]

51. Jaimy, K.B.; Safeena, V.P.; Ghosh, S.; Hebalkarb, N.Y.; Warrier, K.G.K. Photocatalytic activity enhancement in doped titanium dioxide by crystal defects. Dalton Trans. 2012, 41, 4824.

52. Umar, A.; Kumar, R.; Kumar, G.; Algarni, H.; Kim, S. Effect of annealing temperature on the properties and photocatalytic efficiencies of ZnO nanoparticles. J. Alloy. Compd. 2015, 648, 46-52. [CrossRef]

53. Kanchana, S.; Chithra, M.J.; Ernest, S.; Pushpanathan, K. Violet emission from Fe doped ZnO nanoparticles synthesized by precipitation method. J. Lumin. 2016, 176, 6-14. [CrossRef]

54. Kleinwechter, H.; Janzen, C.; Knipping, J.; Wiggers, H.; Roth, P. Formation and properties of ZnO nano-particles from gas phase synthesis processes. J. Mater. Sci. 2002, 37, 4349. [CrossRef]

55. Chen, J.; Feng, Z.C.; Ying, P.L.; Li, M.J.; Han, B.; Li, C. The visible luminescent characteristics of $\mathrm{ZnO}$ supported on $\mathrm{SiO}_{2}$ powder. Phys. Chem. Chem. Phys. 2004, 6, 4473. [CrossRef]

56. Mehrotra, K.; Yablonsky, G.S.; Ray, A.K. Macro kinetic studies for photocatalytic degradation of benzoic acid in immobilized systems. Chemosphere 2005, 60, 1427-1436. [CrossRef] [PubMed]

57. Butalid, R.J.B.; Cristobal, A.P.S.; Montallana, A.D.S.; Vasquez, M.R., Jr. Stability of $\mathrm{TiO}_{2}$-coated $\mathrm{ZnO}$ photocatalytic thin films for photodegradation of methylene blue. J. Vac. Sci. Technol. B 2020, 38, 062205. [CrossRef]

58. Alharthi, F.A.; Alghamdi, A.A.; Al-Zaqri, N.; Alanazi, H.S.; Alsyahi, A.A.; el Marghany, A.; Ahmad, N. Facile one-pot green synthesis of Ag-ZnO Nanocomposites using potato peeland their Ag concentration dependent photocatalytic properties. Sci. Rep. 2020, 10, 20229. [CrossRef] [PubMed]

59. Sunaina; Devi, S.; Nishanthi, S.T.; Mehta, S.K.; Ganguli, A.K.; Jha, M. Surface photosensitization of ZnO by ZnS to enhance the photodegradation efficiency for organic pollutants. SN Appl. Sci. 2021, 3, 689. [CrossRef] 